Vol. 6(3), pp. 57-65, March 2014

DOI: $10.5897 / \mathrm{J}$ MA 11.103

Artic le Number: 8C 4571B44112

ISSN 2141-2308

Copyright (c) 2014

Author(s) reta in the copyright of this a ricle

http://www.academic joumals.org/J MA

Journal of Microbiology and Antimicrobials

Full Length Research Paper

\title{
Characterization of antifungal compounds produced by Pseudomonas stutzeri (EGB3) isolated from gut of earthworm (Eisenia foetida)
}

\author{
N. D. Prasanna ${ }^{1 *}$, K. Vijayalakshmi ${ }^{1}$, K. Seshagirirao ${ }^{2}$ and S. K. Shaheen ${ }^{1}$ \\ ${ }^{1}$ Department of Applied Microbiology, Sri Padmavathi Mahila University, Tirupathi-517502, India. \\ ${ }^{2}$ Department of Plant Sciences, University of Hyderabad-500044, India.
}

Received 20 July, 2011; Accepted 8 April, 2014

\begin{abstract}
Strain EGB3 was isolated from the gut of earthworm fed with sterile soil and identified as Pseudomonas stutzeri on the basis of biochemical tests and by comparison of 16S rDNA sequences. This bacterium exhibits a broad-spectrum antifungal activity towards soil borne phytopathogenic fungi (Fusarium oxysporum, Fusarium solani, Fusarium moniliformae, Fusarium udum, Macrophomena phaseolina, Rhizoctonia solani, Colletotrichum capsicii, Aspergillus flavus, and Aspergillus niger). The antifungal metabolite produced by EGB3 was extracted and characterized to determine the nature of the active molecules (volatile and non-volatile). The bioactive compound was thermostable upto $80^{\circ} \mathrm{C}$ for $10 \mathrm{~min}$. The zone of inhibition was observed after $6 \mathrm{~h}$ of incubation and increased up to $36 \mathrm{~h}$ and there was no change in zone of inhibition after $36 \mathrm{~h}$ of incubation. EGB3 was an antagonist against a range of phytopathogenic fungi that infect groundnut plants.
\end{abstract}

Key words: phytopathogenic fungi, EGB3, Pseudomonas stutzeri, antifungal metabolites.

\section{INTRODUCTION}

Microorganisms in nature compete for survival in their habitats. This biological task of antagonistic nature is achieved by the development of competitive mechanisms such as the production of antimicrobial agents like antibiotics, siderophores, toxins and enzymes, etc. Antagonistic microorganisms, by their interaction with various pathogens, play a major role in microbial equilibrium and serve as powerful agents for biological disease control. The interaction between antimicrobial agents produced by bacteria and plant pathogens has been studied extensively, and the application of antimicrobial agents in the protection of crops is promising, besides their pharmaceutical applications.

In the post-industrial information age, biotechnological era is replacing largely the mechanical and chemical eras of the industrial age. In the back drop of globalization, there is a reawakening to our ultimate reliance on biological processes. There has been a rise in studies of relationships between invertebrates, microorganisms and plant/soil development (Edwards et al., 1988). Investigation of the interaction of microorganisms with soil invertebrates is one of the ways to study the development in biogeocenoses

*Corresponding author: E-mail: ndprasanna@gmail.com. Tel: 9492373928.

Author(s) agree that this article remain permanently open access under the terms of the $\underline{\text { Creative Commons Attribution License } 4.0}$ International License 
(Szabo, 1974; Chu et al., 1987). As earthworms are used in bioconversion of organic wastes their gut flora must be explored as they are ecofriendly and farmers best friends. So the present study was focused on the gut bacteria and their activities.

Since the time of the "Green Revolution" promoted in the early part of $20^{\text {th }}$ century, the food production was boosted but without foreseeing some of its ill effects. With the recent realizations to maintain ecological balance for the sustenance of agricultural production, farmers and scientists alike are aiming at finding an alternative to chemical agriculture. The potential use of microbe based biocontrol agents as replacement or supplement for agrochemicals has been addressed in many recent reports (Shimizu et al., 2000; Aghighi et al., 2004; Shahidi Bonjar et al., 2006).

\section{MATERIALS AND METHODS}

\section{Collection of earthworms}

The most prevalent earthworms (Eisenia foetida) employed in vermicomposting was collected from top ploughed horizon (0-20 $\mathrm{cm}$ ) of vermicompost pits from Agricultural College in the Tirupati Region and fed with sterile soil for one week and used for preparation of gut homogenates.

\section{Preparation of earthworm gut homogenates}

Homogenates were prepared by using aseptic techniques. Worms were washed with sterile (autoclaved) tap water and allowed to starve for $24 \mathrm{~h}$ to exclude the microbes associated with soil and other organic wastes of the gut. After starvation, the worms were washed thrice with sterile double distilled water, weighed and sedated with ethanol (40\%). The gut was dissected; contents were pooled, weighed ( $1 \mathrm{~g}$ wet weight) and mixed in homogenization buffer $(10 \mathrm{ml})$ for 5 min using a vortex mixer. Solid matter was separated after centrifugation at $10,000 \mathrm{rpm}$ for $15 \mathrm{~min}$, supernatant was filtered (pore size $0.2 \mu \mathrm{m}$ ) and used for isolation of microflora of earthworm gut (Cappuccino and Sharman, 1999; Toyota and Kimura, 2000).

Isolation of bacteria capable of producing antimicrobial agents using crowed plate technique

The growth medium used for isolation and maintenance of the isolates was on Trypic Soya Agar (TSA). One milliliter of earthworm gut homogenate was diluted in $9 \mathrm{ml}$ of $0.85 \%$ physiological saline solution $\left(10^{-1}\right)$. The sample suspensions were homogenized by shaking at $200 \mathrm{rpm}$ for $15 \mathrm{~min}$ at $37^{\circ} \mathrm{C}$. Serial dilutions were performed and plates were incubated at $37^{\circ} \mathrm{C}$ for $48 \mathrm{~h}$. Colonies showing antagonisms were isolated, designated as earthworm gut bacteria (EGB) isolates and used for further studies (Cuppucino and Sharman, 1999).

\section{Screening of the isolates for antagonism against plant pathogenic fungi}

\section{Test organisms}

Nine fungal cultures (Fusarium oxysporum, Fusarium solani,
Fusarium moniliformae, Fusarium udum, Macrophomena phaseolina, Rhizoctonia solani, Colletotrichum capsicii, Aspergillus flavus, and Aspergillus niger) were used to determine the antifungal activity of the earthworm gut bacteria (EGB). The phytopathogenic fungi were isolated from groundnut crops obtained from D.O.R Agricultural University, Rajendranagar, Hyderabad, India.

\section{Fungal inoculum preparation}

Spore suspensions of fungal cultures were prepared in potato dextrose broth. About $100 \mathrm{ml}$ of potato dextrose broth were placed in a $250 \mathrm{ml}$ flask and the broth was inoculated with a small portion of the fungal culture on a shaker ( $8 \mathrm{~h}$ each day) at room temperature $\left(28 \pm 2^{\circ} \mathrm{C}\right)$ for seven days. The entire content of the flask was diluted with sterile distilled water to get the final inoculum approximately with $2.5 \times 10^{5}$ spores $/ \mathrm{ml}$.

\section{Well diffusion method}

Antifungal activity of EGB3 against the test fungi was assayed using the agar well diffusion method. Potato dextrose agar plates were prepared aseptically and wells of $10 \mathrm{~mm}$ diameter were made by using a sterile cork borer. Each plate consisted of three wells, of which one well was filled with EGB, standard antibiotic solution and control (sterile Trypic soya broth), respectively The plates were incubated at $28^{\circ} \mathrm{C}$ for $72 \mathrm{~h}$.

\section{Measuring the zone of inhibition}

The zone of inhibition against the growth of phytopathogenic fungi was recorded after incubating the plates for $72 \mathrm{~h}$. Experiments were repeated in duplicates, the representative readings were the averages. The definite zone of inhibition of any dimension surrounding the well was measured accurately to the nearest $\mathrm{mm}$ by means of a ruler and illuminated colony counter. In all such cases where the zone of inhibition was found to be more (than that of the positive control), it was ascertained whether the activity was microbicidal. This was achieved by transferring a loop of content from clear zones into sterile broth with a known microorganism and incubating them for three to four days. A clear broth indicated microbicidal activity. Simultaneously, the standard antifungal compound Nystatin $(100 \mu \mathrm{g} / \mathrm{ml})$ was used as control for all the microbes under study appropriately in similar conditions so as to compare the degree of inhibition exhibited by the culture filtrate of EGB3 strain with the known standard antibiotic.

\section{Molecular characterization of the EGB3}

\section{Genomic DNA Extraction of the EGB3}

Genomic DNA extraction was done using the EGB3 isolate following the method described by Sambrook et al. (1989). The EGB3 were grown in Luria broth for $24 \mathrm{~h}$ at $37^{\circ} \mathrm{C}$. The cells were harvested by centrifugation at $10000 \mathrm{rpm}$ for $5 \mathrm{~min}$. The pellet was suspended in STE buffer $-\mathrm{I}$ and centrifuged at $10000 \mathrm{rpm}$ for 10 $\mathrm{min}$. The pellet was resuspended in STE buffer $-\mathrm{Il}$ and $50 \mu \mathrm{l}$ of $10 \%$ sodium dodecyl sulphate (SDS); the cells were left at $-80^{\circ} \mathrm{C}$ for 30 $\mathrm{min}$. To the cell suspension, $500 \mu \mathrm{l}$ of phenol-chloroform was added and spinned for $10 \mathrm{~min}$. The supernatant was collected and $100 \mu \mathrm{l}$ of chloroform: isoamyl alcohol (1:1) was added. To the supernatant obtained by centrifuging at $10000 \mathrm{rpm}, 1 / 10^{\text {th }}$ volume of sodium acetate and 2.5 volumes of ice cold $100 \%$ ethanol were added and centrifuged for $10 \mathrm{~min}$ at $10000 \mathrm{rpm}$. The supernatant was removed and pellet was dried for $3 \mathrm{~h}$. DNA was resuspended in $20 \mu \mathrm{l}$ of 
Table 1a. Reaction mixture concentrations.

\begin{tabular}{|c|c|}
\hline PCR- Reagent per reaction & Value $(\mu \mathrm{l})$ \\
\hline $10 \times$ Buffer & 5.0 \\
\hline $20 \mathrm{mM} \mathrm{MgCl}_{2}$ & 4.0 \\
\hline 20 mM dNTPs & 0.25 \\
\hline $5^{\prime}$ primer $(10 \mu \mathrm{M})$ Forward & 1.0 \\
\hline 3' primer $(10 \mu \mathrm{M})$ & 1.0 \\
\hline DNA template & 1.0 \\
\hline Taq DNA polymerase & 0.5 \\
\hline $\mathrm{MQ} \mathrm{H}_{2} \mathrm{O}$ & 40.5 \\
\hline Total & 50.00 \\
\hline
\end{tabular}

Table 1b. PCR programme.

\begin{tabular}{lcc}
\hline Programme & Temperature $\left({ }^{\circ} \mathbf{C}\right)$ & Time $(\min )$ \\
\hline Initial denaturation & 94 & 3 \\
Denaturation & 94 & 1 \\
Annealing & 51 & 1 \\
Extension & 72 & 1 \\
Final extension & 72 & 5 \\
\hline
\end{tabular}

distilled water.

\section{Agarose gel electrophoresis}

Purity of the isolated DNA was checked by electrophoresis in $0.7 \%$ agarose gel. Agarose gel was prepared by dissolving $0.7 \%$ of agarose in IX Tris-borate buffer. $20 \mu \mathrm{l}$ of ethidium bromide (10 $\mathrm{mg} / \mathrm{ml}$ ) was added to agarose gel and placed in the electrophoresis tank containing $1 \mathrm{X}$ Tris-borate buffer. The DNA samples and $10 \mathrm{~kb}$ DNA marker were loaded into agarose wells and was run for $30 \mathrm{~min}$ at $100 \mathrm{~V}$. The gel was observed under UV transilluminator (Sadasivam and Manickyam, 1996).

\section{DNA sequencing}

The 16S rDNA of the EGB3 that exhibited major inhibition patterns were sent to be sequenced at BIOSERVE, Hyderabad, India.

\section{Amplification of 165 ribosomal DNA}

Phylogenetic analysis of $16 \mathrm{~S}$ ribosomal gene is an important tool to differentiate Pseudomonas and other related genera from each other. To identify bacterial isolate of interest, the genomic DNA was extracted followed by amplification of $16 \mathrm{~S}$ ribosomal DNA by PCR. The PCR product was purified and sequenced. The gene sequence obtained was blast searched to get homologous sequences followed by phylogenetic analysis of the isolates.

\section{Primers for 16S rRNA PCR}

PCR primer pair designed using consensus degenerate sequence, which was capable of amplifying a wide variety of bacterial taxa was used in the study.

\begin{abstract}
PCR of 165 rDNA
PCR parameters were standardized initially for amplifying $16 S$ rDNA sequence of the isolate at $30 \mu \mathrm{g} / \mathrm{ml}$ concentration of genomic DNA in a total volume of $50 \mu$ reaction mixture at a gradient temperature of 50 to $60^{\circ} \mathrm{C}$. As positive control of PCR, a single colony of Pseudomonas fluorescens was picked up from the plate and resuspended in $20 \mu \mathrm{l}$ of water in PCR tube. The tubes were heated at $98^{\circ} \mathrm{C}$ for $5 \mathrm{~min}$ and the sample was used as template. In negative control reaction mixture, the Taq polymerase was omitted. The reaction mixture concentrations and PCR programme used for amplification are given in Table $1 \mathrm{a}$ and $\mathrm{b}$. PCR programme consisted of the following steps that were run for 40 cycles (Table 1b).
\end{abstract}

\section{Agarose gel electrophoresis}

After initial standardization of PCR, the optimum temperature was used for further amplification with $100 \mu \mathrm{l}$ of amplification reaction. The PCR product was visualized on $1.5 \%(\mathrm{w} / \mathrm{v})$ agarose preparative gel using standard DNA markers and run at $50^{\circ} \mathrm{V}$ for 45 min. The gel was visualized under UV transilluminator.

\section{Purification of PCR product}

The excised agarose slice with DNA fragment gel in an Eppendroff tube was weighed and $2.5 \mathrm{mM}$ of sodium iodide was added. The tubes were incubated at $55^{\circ} \mathrm{C}$ for $5 \mathrm{~min} .15 \mu \mathrm{l}$ of silica solution was added and spinned for $30 \mathrm{~s}$. This was incubated at $55^{\circ} \mathrm{C}$ for $5 \mathrm{~min}$. Pellet was collected by centrifugation at $12000 \mathrm{rpm}$ for $30 \mathrm{~s}$ and supernatant was discarded. Pellet was washed with wash buffer for three times and air dried for $15 \mathrm{~min} .25 \mu$ of Tris-EDTA (TE) buffer was added to elute DNA from the silica matrix. Eluted DNA was checked again using $1.5 \%$ agarose gel electrophoresis and sequencing was attempted.

\section{Sequencing of the 165 rDNA}

Purified DNA product was adjusted to $100 \mathrm{mg} / \mu \mathrm{l}$ concentration in $\mathrm{MQ}$ water $(\mathrm{pH}$ 8) and sequencing was carried out using primers. Sequencing was carried out in a 313 OXL capillary DNA sequencer utilizing thermocycling reaction Big Dye termination version 3:1. The 16S rRNA gene was sequenced in both directions by primer walking using primers directed to the conserved regions within the gene.

\section{Phylogenetic analysis}

The DNA sequences of the 16S rRNA gene from the isolate of interest were edited manually and blast searched individually to search out sequences of homology. The sequences were aligned using the programme CLUSTAL W (Wisconsin, 1994). The aligned sequences were applied to genetic distance by using neighborjoining method for phylogenetic inference. Phylogenetic tree was visualized using tree program.

\section{Characterization of antifungal compound}

Preliminary characterization of the antimicrobial agent from the 
Table 2. Antifungal activity of antagonists against phytopathogenic fungi by well diffusion method.

\begin{tabular}{|c|c|c|c|c|c|c|c|c|c|c|c|c|c|c|c|c|c|c|c|c|}
\hline \multirow{2}{*}{ Test organism } & \multicolumn{20}{|c|}{ EGB-Isolates } \\
\hline & 1 & 2 & 3 & 4 & 5 & 6 & 7 & 8 & 9 & 10 & 11 & 12 & 13 & 14 & 15 & 16 & 17 & 18 & 19 & 20 \\
\hline F. oxysporum & + & + & +++ & + & + & + & + & - & - & + & - & + & - & - & + & - & - & + & + & - \\
\hline F. udum & - & + & +++ & + & + & + & + & - & - & + & - & + & - & - & + & - & - & + & + & - \\
\hline F. solani & - & + & +++ & + & + & + & + & + & + & ++ & - & + & - & - & + & - & - & + & + & - \\
\hline F. moniliformae & - & + & +++ & + & - & + & + & - & + & + & - & + & - & - & + & - & - & + & + & - \\
\hline A. flavus & + & - & ++ & + & + & + & - & - & - & - & + & + & + & - & + & - & + & + & - & + \\
\hline A. niger & - & - & ++ & + & + & + & - & + & - & - & + & + & + & - & + & + & - & + & - & + \\
\hline M. phaseolina & - & - & + & - & - & + & + & - & + & - & - & + & - & - & + & + & - & + & - & + \\
\hline R. solani & - & - & + & + & - & + & - & - & - & - & - & + & - & - & + & + & $-1+$ & + & + & + \\
\hline C. capscii & - & - & + & - & - & + & - & - & - & - & - & + & - & + & + & - & + & - & + & - \\
\hline
\end{tabular}

5-9 mm (+), weak inhibition; 10-20 mm (++), moderate inhibition; >20 mm (+++), strong inhibition; 1-4 mm (-/+), very slight inhibition; (-), no inhibition.

active strain was carried out to determine the nature of the active molecules.

\section{Production of inhibitory volatile substances by antagonists}

The antagonists were tested for the production of volatile inhibitory compounds by inverted plate technique adopted by Dennis and Webster (1971a). In this experiment, $0.1 \mathrm{ml}$ of overnight grown culture of bacterial antagonist was placed on nutrient agar in Petri plates and spread using sterile glass spreader. Mycelial disc of 5 $\mathrm{mm}$ size of test pathogenic fungi was removed from the actively grown culture and was incubated at the center of separate PDA plates. Subsequently, the plates inoculated with the pathogen were inverted over the plates inoculated with antagonist. The junction of both the dishes was sealed with parafilm. The plates with pathogen dishes inverted and sealed over the plates with uninoculated media were maintained as control, and three replicates were maintained. The inoculated plates were incubated at $28^{\circ} \mathrm{C}$ for five days. The growth of the pathogen after the incubation was measured and per cent inhibition of mycelial growth over the control was calculated as suggested by Dennis and Webster (1971b).

\section{Screening for chitinase activity on solid medium}

To check the chitinase production, the EGB3 strain was inoculated on chitin agar medium containing $0.5 \%$ colloidal chitin obtained as above. The inoculated cultures were incubated at $37^{\circ} \mathrm{C}$ for $72 \mathrm{~h}$. The plates were observed for a clear halo region around the growth of the organism.

\section{Determination of antifungal compound}

Preliminary screening for antifungal activity was performed on PDA medium without supplementation of $\mathrm{FeCl}_{3}$. Under this condition, fungal growth inhibition could be either due to the production of siderophores or the antifungal metabolites. To determine whether the antifungal metabolites or the siderophores responsible for the antagonistic property, the EGB3 triplicates was grown on potato dextrose agar plates supplemented with $1 \%$ ferric chloride and tested for antagonistic activity by agar well diffusion method. Absence of inhibition on PDA plates supplemented with $1 \%$ ferric chloride indicates siderophore mediation. Experiments were repeated thrice.

\section{Thermostability of the antifungal compound}

The thermostability of the active compound showing antifungal activity to temperature was tested by heating the supernatants at $80^{\circ} \mathrm{C}$ for $10 \mathrm{~min}$ and $121^{\circ} \mathrm{C}$ for $15 \mathrm{~min}$. The heated and unheated supernatants were tested for their antifungal activities as described above.

\section{Enzyme treatment}

To determine whether the effective compounds are proteinaceous in nature, the sample was treated with trypsin, protease, and proteinase enzyme K (Egan et al., 2001b). The respective enzyme was added to the sample to get a concentration of $200 \mu \mathrm{g} / \mathrm{ml}$. The mixture was incubated for $1 \mathrm{~h}$ at $37^{\circ} \mathrm{C}$ and $20 \mathrm{~min}$ for proteinase $\mathrm{K}$, $10 \mathrm{~min}$ for trypsin and tested for antimicrobial activity. Untreated supernatants were maintained as controls.

\section{Effect of Time on the production of antifungal compound}

EGB3 was grown on TSA and incubated at $30^{\circ} \mathrm{C}$ for $72 \mathrm{~h}$ and sampled after every $6 \mathrm{~h}$. All the samples were centrifuged and filtered using Millipore filters $(0.2 \mu \mathrm{m})$ and the activity of the filtrates was checked by Agar Well Diffusion Method.

\section{RESULTS}

A total of 20 bacteria had showed zone of inhibition.

\section{Screening the isolates for antagonism against plant pathogenic fungi}

Twenty bacteria isolated from the earthworm gut were screened for their antagonistic activity against phytopathogenic fungi (test organisms) by dual culture and well diffusion method. Of twenty bacteria screened, strong ( $>20 \mathrm{~mm}$ ) antifungal activity was shown by EGB3 against the test phytopathogenic fungi like, Fusarium oxsysporum, Fusarium udum, Fusarium solani and Fusarium moniliformae. Moderate (10-20) inhibition was shown against Aspergillus niger and Aspergillus flavus. Weak (1-4 mm) inhibition was observed aganist Macrophomina phaseolina, Rhizoctonia solani and C. capscii. The diameter of zone of inhibition (in $\mathrm{mm}$ ), was ranging from 5 to $25 \mathrm{~mm}$ (Table 2). 


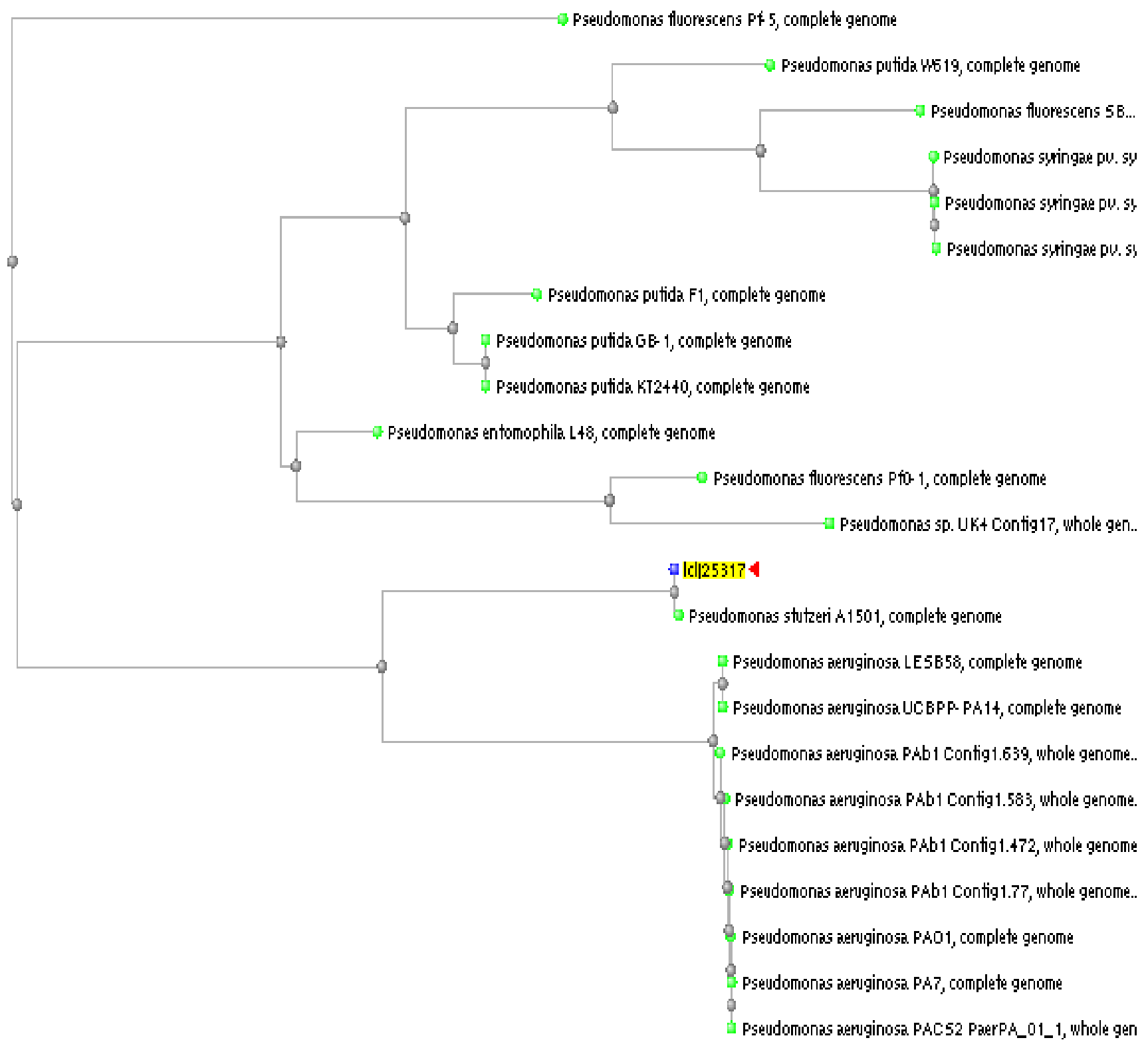

Figure 1. Phylogenetic tree of EGB3 (using neighbor joining method).

\section{Molecular characterization of EGB3}

Based on the biochemical, physiological tests and specific tests performed for EGB3, the strain was identified as Pseudomonas stutzeri which was further confirmed at the species level by the molecular characterization.

\section{PCR amplification of 16S rRNA}

A product of $708 \mathrm{bp}$ was obtained and the optimum temperature for amplification of the gene was $55^{\circ} \mathrm{C}$ and maximum product was $30 \mu \mathrm{g} / \mathrm{ml}$. The BLAST results revealed $100 \%$ homology with $P$. stutzeri. The $16 \mathrm{~S}$ rRNA sequence of the EGB3 was genotypically similar to $P$. stutzeri.

\section{BLAST search of the 16S rRNA and identification EGB3}

The biochemical differentiating characters like fluorescent pigmentation test, utilization of maltose, starch, Stewart's arginine test and denitrification also match with reported characters of $P$. stutzeri. Thus based on the morphological, biochemical and genetic characters studied, the isolate EGB3 was identified as $P$. stutzeri (Figure 1). 


\section{Determination of Antifungal activity of the compound}

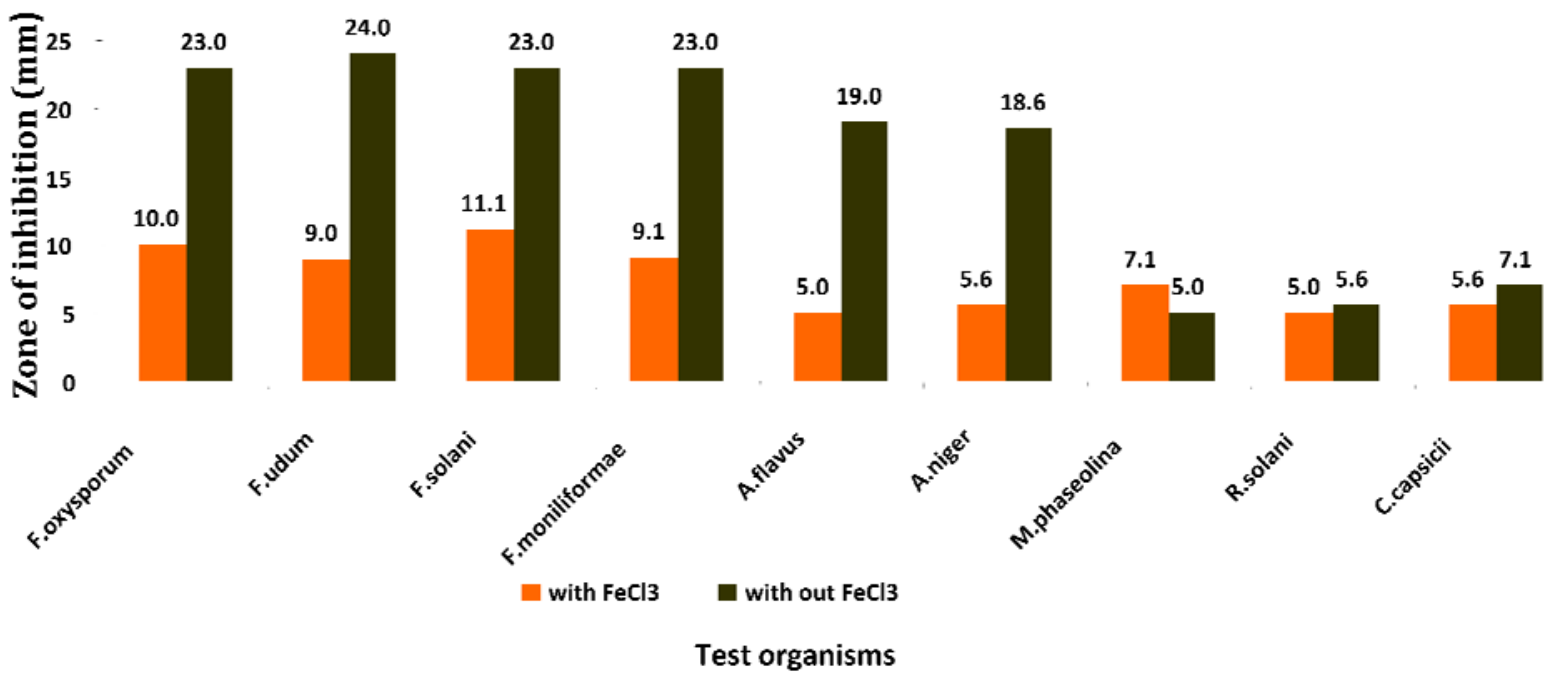

Figure 2. Determination of antifungal activity of the compound with and without $\mathrm{FeCl}_{3}$ in $\mathrm{mm}$.

\section{Characterization of antifungal compound}

The preliminary characterization of antifungal compound for its nature was determined by its sensitivity (towards nutrients, heat, enzymes etc) and conditions for production.

\section{Production of inhibitory volatile substances by antagonist}

It has been shown that the isolate EGB3 was not producing any volatile metabolites which could inhibit the mycelial growth.

\section{Screening for chitinase activity}

At $72 \mathrm{~h}$ of incubation a clear halo was observed around EGB3 strain, which was clearly visible after the Congo red staining showing the hydrolysis of the colloidal chitin by chitinase.

\section{Determination of antifungal activity of the compound with and without $\mathrm{FeCl}_{3}$}

Determination of antifungal compound was one of the important factors which explain the nature of antifungal activity of EGB3. Our results revealed that the antifungal activity was present in both the plates (with and without $\mathrm{FeCl}_{3}$ ). However, Maximum zone of inhibition in plates without $\mathrm{FeCl}_{3}$ produced against all test organisms except M. phaseolina (Figure 2).

\section{Thermostability of the antifungal compound}

To determine the thermostability of the antifungal compound it was heated at 80 and $121^{\circ} \mathrm{C}$ for $10 \mathrm{~min}$ and was tested for antifungal activity. The results revealed that the bioactive compound was thermostable upto $80^{\circ} \mathrm{C}$ for $10 \mathrm{~min}$ and the activity was completely destroyed at $121^{\circ} \mathrm{C}$ (Table 3).

\section{Enzyme treatment}

The results showed that the bioactive compound had no effect with both of the enzymes (Figure 3).

\section{Effect of time on the production of antifungal compound}

The zone of inhibition was observed after $6 \mathrm{~h}$ of incubation and increased up to $36 \mathrm{~h}$ and there was no change in zone of inhibition after $36 \mathrm{~h}$ of incubation (Figure 4). It suggests the importance of the time of incubation for production of antifungal compounds.

\section{DISSCUSION}

Earthworms are important and much neglected 
Table 3. Thermostability of antifungal compound.

\begin{tabular}{lcc}
\hline \multirow{2}{*}{ Test organism } & \multicolumn{2}{c}{ Inhibition zone in $\mathbf{~ m m}$} \\
\cline { 2 - 3 } & $\mathbf{8 0 ^ { \circ } \mathbf { C } \text { for } \mathbf { 1 0 } \mathbf { ~ m i n }}$ & $\mathbf{1 2 1 ^ { \circ } \mathbf { C } \text { for } \mathbf { 1 0 } \mathbf { ~ m i n }}$ \\
\hline F. oxysporum & +++ & - \\
F. udum & +++ & - \\
F. solani & +++ & - \\
F. moniliformae & +++ & - \\
A. flavus & ++ & - \\
A. niger & ++ & - \\
M. phaseolina & + & - \\
R. solani & + & - \\
C. capscii & + & - \\
\hline
\end{tabular}

5-10 mm (+), weak inhibition; 10-20 mm (++), moderate inhibition; >20 mm $(+++)$, strong inhibition; (-), no inhibition.

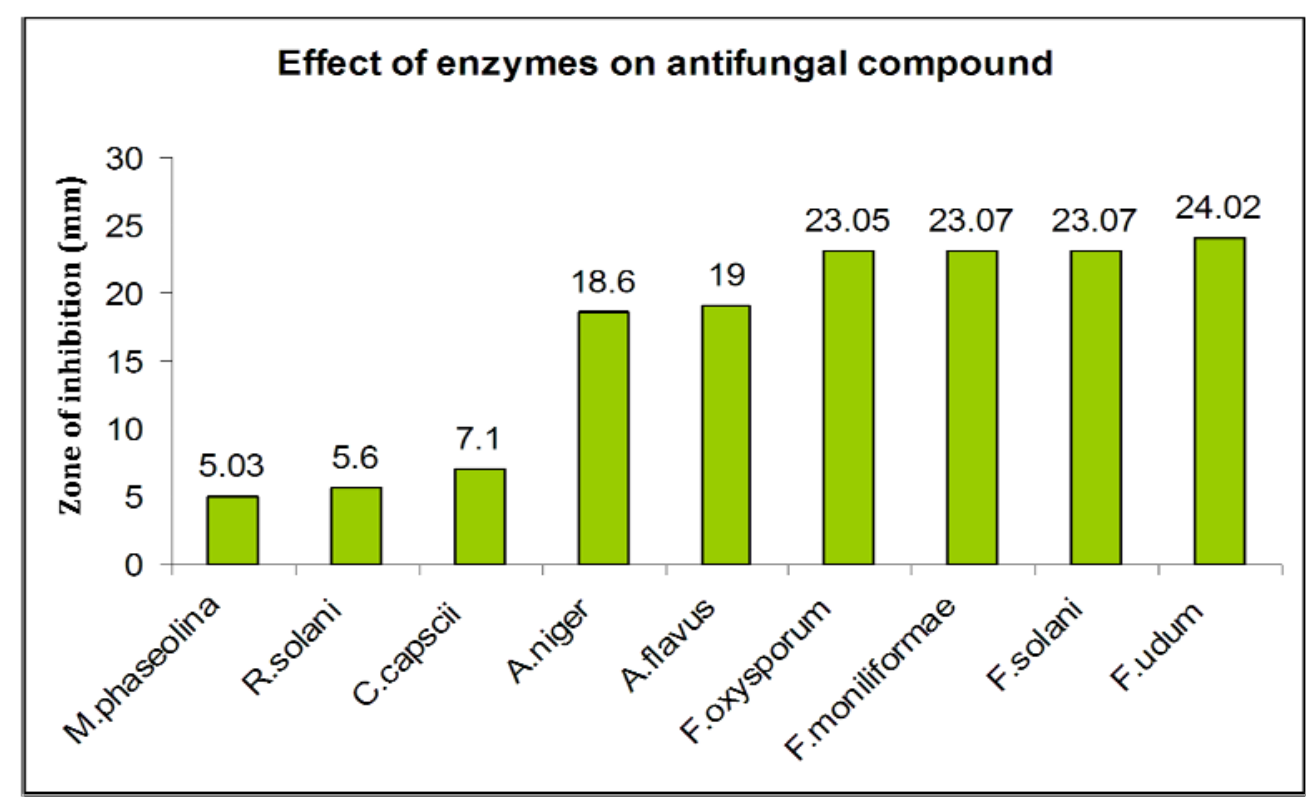

Figure 3. Effect of enzymes on antifungal compound.

components of ecosystem. By understanding the key role of earthworms in many biogeochemical cycles and in soil development, requires an understanding of the gut microbial diversity and their influences on soil and plant growth. The search for bioactive metabolites especially from bacteria requires screening of a large number of isolates. The discovery of an antifungal compounds will be promising if diverse bacteria are sampled and screened. Earthworm not only disperses microorganisms important in food production but also associated with mycorrhizae and other root symbionts, biocontrol agents and microbial antagonists of plant pathogens (Edwards and Bohlen 1996). The physico-chemical factors in the earthworm gut gives an evident that the gut environment has certain beneficial bacterial taxonomic groups.

The study had focused upon the production of antimicrobial substances producing bacteria from gut of earthworm (Eisenia foetida), their role against some phytopathogens while promoting plant growth.

Microorganisms have been evaluated as a source of biocontrol agents based on their distribution in various habitats (Huck et al., 1991; Crawford et al., 1993; Gerhardson, 2002). Bacteria produce more than half of the world's antimicrobials and are consequently becoming valuable tools in the field of biological control. This study had highlighted antifungal activity of the earthworm gut bacteria 3 (EGB3) which emphasized their importance as candidates for further investigation in biological control against test phytopathogens and as plant growth promoters. It is anticipated that the isolation, characterization and the study on bacteria can be useful in the discovery of new antimicrobial substances. The natural roles played by earthworm to protect soil health may be replaced by earthworm gut flora. 


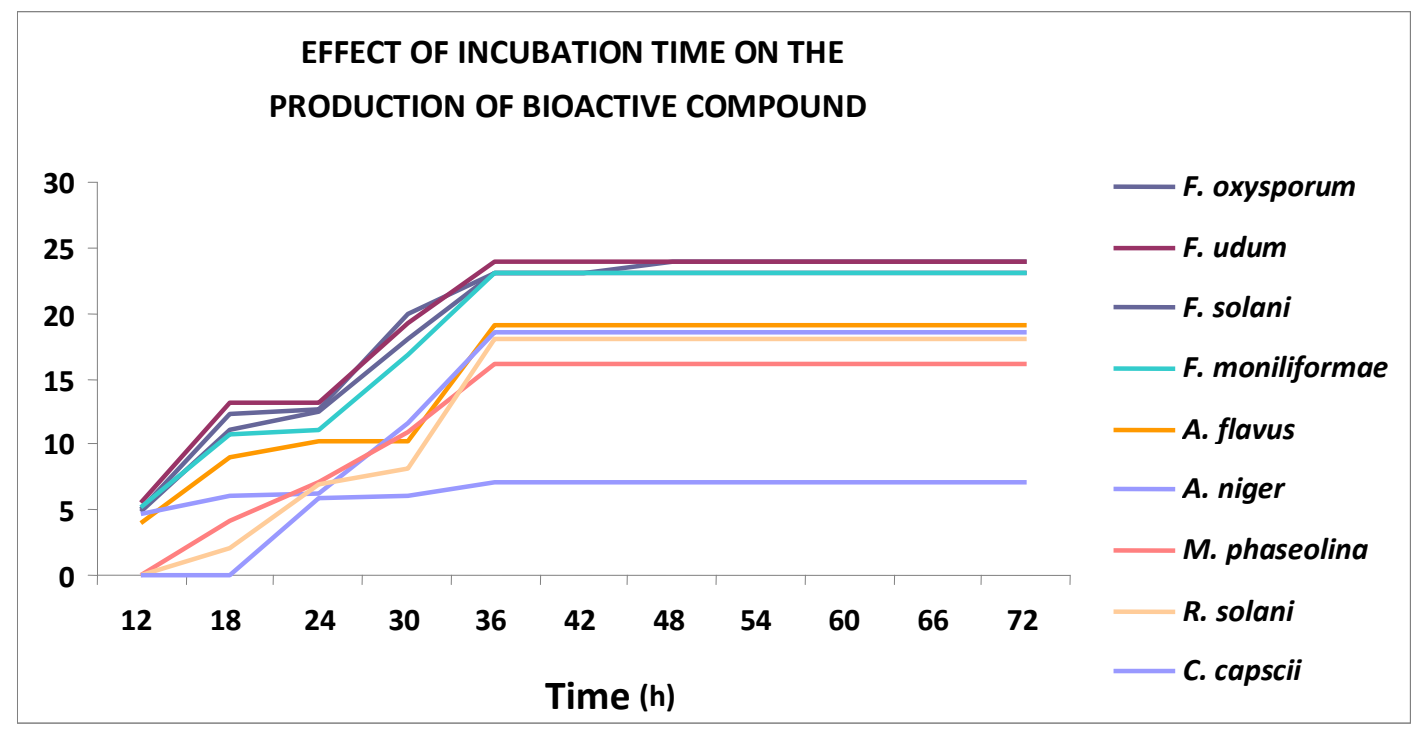

Figure 4. Effect of incubation time on the production of antifungal compound.

In the present study the antimicrobial substance producing bacteria were isolated from the Eisenia foetida gut by Crowded Plate Technique. Twenty isolates showing antagonistic activity were characterized up to genus level and among them one broad antimicrobial activity exhibiting bacterium was named as EGB3 and studied up to species level. It was identified and confirmed as $P$. stutzeri by $16 \mathrm{~S}$ rRNA sequencing. In the present study the isolation rate of antifungal bacteria was approximately $20 \%$.

The synthetic fungicides, pesticides etc., commonly used to control the plant diseases, are causing soil, air, food and water contamination. These will tend to develop resistance in the organisms and adversely affect other beneficial microorganisms. The biological control of soil borne plant pathogens with microorganisms is the ideal option in controlling attack by pathogens since they provide the front line defense especially for roots.

Pathogen suppression by antagonistic microorganisms can result from one or more mechanisms depending on the particular antagonist involved (Barea et al., 2005). An effective biocontrol agent often acts through a combination of several different mechanisms (Whipps 2001). Earlier reports showed that microorganisms capable of hydrolyzing the fungal cell wall are the most efficient in controlling the population of fungal pathogens (Mitchell et al., 1961; Shapira et al., 1989; Sivan and Chet, 1989; Chet et al., 1990; Haran et al., 1993; Tanaka and Watanabe, 1995; Bapat and Shah, 2000; Wang et al., 2002). Many Pseudomonas and Bacillus species are capable of producing hydrolytic enzymes. For example, $P$. stutzeri produces extracellular chitinase which lyse the pathogen Fusarium sp., Clostridium werneckii and Bacillus cepaciacan hydrolyze fusaric acid produced by Fusarium (Bashan and de-Bashan, 2005).
Similar antagonistic activity was studied in the present work to know different mechanisms used by the isolate to suppress fungal pathogens. In the present study the antagonistic activity of EGB3 is by producing both siderophore and chitinase for disease suppression. The antifungal compound isolated is proteinaceous because it was inactivated by proteases.

\section{Conflict of Interests}

The author(s) have not declared any conflict of interests.

\section{REFERENCES}

Aghighi S, Shahidi BGH, Rawashdeh R, Batayneh S, Saadoun I (2004). First report of antifungal spectra of activity of Iranian actinomycetes strains against Alternaria solani, Alternaria alternate, Fusarium solani, Phytophthora megasperma, verticillium dahliae and Saccharomyces cerevisiae. Asian J. Plant Sci. 3:463-471.

Bapat S, Shah AK (2000). Biological control of fusarium wilt of pigeon pea by Bacillus brevis. Can. J. Microbiol. 46:125-132.

Barea JM, Pozo MJ, Azcón R, Azcón-Aguilar C (2005). Microbial cooperation in the rhizosphere. J. Exp. Bot. 56:1761-1778.

Bashan Y, de-Bashan LE (2005). Bacteria. In: Encyclopaedia of Soils in the Environment. Hillel D. (ed.). Elsevier, Oxford, U.K. 1:103-115.

Cappuccino JG, Sherman N (1999). Crowed plate technique. In Microbiology a Laboratory Manual. International student edition. $4^{\text {th }}$ edition. Addison Wesely Publication.

Chet I, Oradentlich A, Shapira A, Oppenheim A (1990). Mechanisms of biocontrol of soil -borne plant pathogens by Rhizobacteria. Plant Soil 129:85-92.

Chu TL, Szabo IM, Szabo I (1987). Nocardioform gut actinomycetes of Glomeris - Hexasticha Brandt (Diplopoda). Biol. Fertil. Soils. 3:113116.

Crawford DL, Lynch JM, Whipps JM, Ousley MA (1993). Isolation and characterization of actinomycete antagonists of a fungal root pathogen. Appl. Environ. Microbiol. 59:3899-3905.

Dennis C, Webster J (1971a). Antagonistic properties of species groups of Trichoderma.I. Production of Non-volatile antibiotics. Trans. Br. 
Mycol. Soc. 57:25-39.

Dennis C, Webster J (1971b). Antagonistic properties of species groups of Trichoderma.II. Production of Volatile antibiotics. Trans. Br. Mycol. Soc. 57:41-60.

Edwards CA, Bohlen PJ (1996). Biology and Ecology of Earthworms. Chapman and Hall. London. p. 426.

Edwards CA, Fletcher KE (1988). Interactions between earthworms and microorganisms in organic-matter breakdown. Agric. Ecosyst. Environ. 24:235-247.

Egan S, James S, Holmstrom C, Kjelleberg S (2001b). Inhibition of algal spore germination by the marine bacterium Pseudoalteromonas tunicate. FEMS Microbiol. Ecol. 35:67-73.

Gerhardson B (2002). Biological substitutes for pesticides. Trends Biotechnol. 20:338-343.

Haran S, Schickler H, Peer S, Logeman S, Oppenheim A, Chet I (1993). Increased constitutive chitinase activity in transformed Trchoderma harizianum. Biol. Contr. 3:101-108.

Huck TA, Poster N, Bushell ME (1991). Positive selection of antibiotic producing soil isolates. J. Gen. Microbiol. 37:2321-2329.

Mitchell R, Alexander M (1961). The mycolytic phenomenon and biological control of Fusarium in soil. Nat. 190:109-110.

Sadasivam S, Manickam A (1996). Biochemical methods. $2^{\text {nd }}$ edition. New age International (P) Limited, Publishers, New Delhi, pp. 56-58.

Sambrook J, Fritsch EF, Maniatis T (1989). Molecular cloning: A laboratory manual. (Cold Spring Harbor, N.Y. Ed.) $2^{\text {nd }}$ Edition. Cold Spring Harbor Laboratory press.

Shahidi BGH, Farrokhi PR, Bafti S, Aghighi S, Mahdavi MJ, Aghelizadeh A (2006). Laboratory preparation of a new antifungal agent from Streptomyces olivaceus in control of Fusarium oxysporum f.sp. melonis of Cucurbits in Greenhouse. J. Appl. Sci. 6:607-610.

Shapira R, Ordentlich A, Chet I, Oppnheim AB (1989). Control of plant diseases by chitinase expressed from cloned DNA in Escherichia coli. Phytopathol. 79:1246-1249.

Shimizu M, Nakagawa $\mathrm{Y}$, Sato $\mathrm{Y}$, Furumai T, Igaroshi $\mathrm{Y}$, Onaka $\mathrm{H}$, Yoshida R, Kunoh H (2000). Studies on endophytic actinomycetes (I) Streptomyces $\mathrm{sp}$. isolated from Rododendron and its antifungal activity. J. Gen. Plant Pathol. 66:360-366.
Sivan A, Chet I (1989). Degradation of fungal cell walls by lytic enzymes of Trichoderma harizianum. J. Gen. Microbiol. 135:675-682.

Szabo IM (1974). Microbial communities in a Forest - Rendzina Ecosystem: the pattern of microbial communities, Budapest: Acad. Kiado.

Tanaka H, Watanabe T (1995). Glucanases and chitinases of Bacillus circulans WL-12. Ind. J. Microbiol. 14:478-83.

Toyota K, Kimura M (2000). Microbial community indigenous to the earthworm Eisenia foetida. Biol. Fertile Soils 31:187-190.

Wang SL, Shih IL, Liang TW, Wang CH (2002). Purification and characterization of two antifungal chitinases extracellularly produced by Bacillus amyloliquefaciens V656 in a shrimp and crab shell powder. J. Agric Food Chem. 10:2241-2248.

Whipps JM (2001). Microbial interactions and biocontrol in the rhizosphere. J. Exper. Bot. 52:487-511.

Wisconsin Package (1994). Version 8 program manual. Genetics computer group. 575 Science Drive, Medison, Wiscosin, USA. 